\title{
CARM1 Gene
}

National Cancer Institute

\section{Source}

National Cancer Institute. CARM1 Gene. NCI Thesaurus. Code C88221.

This gene is involved in both chromatin remodeling and protein methylation. 